\title{
Ten cases with 46,XX testicular disorder of sex development: single center experience
}

\author{
Emre Can Akinsal ${ }^{1}$, Numan Baydilli ${ }^{1}$, Abdullah Demirtas ${ }^{1}$, Cetin Saatci i ${ }^{2}$, Oguz Ekmekcioglu ${ }^{1}$ \\ ${ }^{1}$ Department of Urology, Erciyes University Medical Faculty, Kayseri, Turkey; ${ }^{2}$ Department of Genetics, \\ Erciyes University Medical Faculty Medical, Kayseri, Turkey
}

\section{ABSTRACT}

Objective: To present clinical, chromosomal and hormonal features of ten cases with SRY-positive 46,XX testicular disorder of sex development who were admitted to our infertility clinic.

Cases and Methods: Records of the cases who were admitted to our infertility clinic between 2004 and 2015 were investigated. Ten 46,XX testicular disorder of sex development cases were detected. Clinical, hormonal and chromosomal assessments were analized.

Results: Mean age at diagnosis was 30.4 , mean body height was $166.9 \mathrm{~cm}$. Hormonal data indicated that the patients had a higher FSH, LH levels, lower TT level and normal E2, PRL levels. Karyotype analysis of all patients confirmed 46,XX karyotype, and FISH analysis showed that SRY gene was positive and translocated to Xp. The AZFa, $\mathrm{AZFb}$ and AZFc regions were absent in 8 cases. In one case AZFb and AZFc incomplete deletion and normal AZFa region was present. In the other one all AZF regions were present.

Conclusion: Gonadal development disorders such as SRY-positive 46,XX testicular disorder of sex development can be diagnosed in infertility clinics during infertility workup. Although these cases had no chance of bearing a child, they should be protected from negative effects of testosterone deficiency by replacement therapies.

\section{ARTICLE INFO}

Keywords:

Chromosome Aberrations;

Infertility; 46, XX Testicular

Disorders of Sex Development

Int Braz J Urol. 2017; 43: 770-5

Submitted for publication:

September 09, 2016

Accepted after revision:

February 09, 2017

Published as Ahead of Print:

March 24, 2017

\section{INTRODUCTION}

Forty Six,XX testicular disorder of sex development (DSD) is a rare clinical condition with a reported incidence of 1:20.000 in newborn males (1). It was first described by De la Chapelle et al. in 1964 (2) By 1996, only 150 patients with classical 46,XX testicular DSD syndrome have been reported (3); however, more than 100 cases were described in the next ten years (4).

The sex-determining region Y gene (SRY) located in $\mathrm{Y}$ chromosome plays a major role in encoding a testis determining factor (TDF) $(5,6)$.
About 90\% of 46,XX testicular DSD have Y chromosomal material including the SRY gene, that is usually translocated to the distal tip of the short arm of X chromosome or autosomal chromosomes. About $10 \%$ of $46, \mathrm{XX}$ testicular DSD cases are negative for SRY gene, which could carry different degrees of masculinization $(4,7)$.

Cases with SRY-positive 46,XX testicular DSD are usually diagnosed after puberty when present with hypogonadism, gynecomastia and infertility (1). Short stature and normal mental development are the other clinical characteristics of these patients (4). 
In this retrospective study, we analized clinical, chromosomal and hormonal features of ten cases with SRY-positive 46,XX testicular DSD who were admitted to our infertility clinic.

\section{CASES AND METHODS}

Records of the cases who were admitted to our infertility clinic between 2004 and 2015 were investigated. Ten 46,XX testicular DSD cases were detected.

Medical/family history and detailed physical examination records, body mass indexes, presence of parenteral consanguinity, records of each testicular volume measured with Prader orchidometer, serum levels of follicle-stimulating hormone (FSH), luteinizing hormone (LH), estradiol (E2), prolactin (PRL), total testosterone (TT), semen analysis results, karyotype and molecular analysis results and Dual-energy X-ray absorptiometry (DEXA) reports, if present, were assessed retrospectively.

Samples of peripheral blood $(3 \mathrm{~mL})$ for chromosomal analysis were collected into $0.3 \mathrm{~mL}$ heparin containing injectors. Conventional method was used on the lymphocyte cultures for karyotype analysis. By $\mathrm{G}$ band staining technique 550 level bands were obtained and twenty metaphases were counted.

The probe mix containing SRY gene, Yp11.31 locus specific probe, labelled in red, and control probes for the X centromere (DXZ1), labelled in blue, and for chromosome Y (DYZ1, the heterochromatic block at Yq12), labelled in green which was used for FISH analysis was purchased from Cytocell (Oxford Gene Technology, UK). After the harvest of cultured blood samples and FISH slide preparation, probe mix was applied according to the manufacturer's instructions, and materials were examined by using the Nikon, ECLIPSE E1000 fluorescent microscope (Tokyo, Japan) and analized with the CytoVision software (CytoVision, AB Imaging, Germany).

Samples of peripheral blood for sequence analysis were collected into commercially available EDTA-treated tubes. DNA was isolated from peripheral blood samples drawn from control, and study groups using High Pure Polyme- rase chain reaction (PCR) Template Preparation Kit (Roche Applied Science). After amplifying AZF regions by using PCR mixture containing 10xPCR Buffer $5 \mu \mathrm{L}, 2.5 \mathrm{mM}$ dNTP $3 \mu \mathrm{L}, 25 \mathrm{mM}$

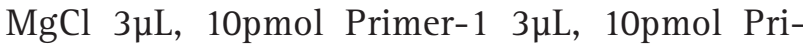
mer-2 $3 \mu \mathrm{L}$, Taq DNA polymerase $0.5 \mu \mathrm{L}$, DNA $5 \mu \mathrm{L}$ and completed to total volume of $50 \mu \mathrm{L}$ by adding water. Primers are specific to AZFa (sy81p1, sy81p2, sy82p1, sy82p2, sy84p1, sy84p2), AZFb (sy127p1, sy127p2, sy142p1, sy142p2, sy164p1, sy164p2, rbm1p1, rbm1p2), and AZFc (sy254p1, sy254p2, sy255p1, sy255p2, sy277p1, sy277p2, cdyp 1, cdyp2, bpy2p1, bpy2p2) regions and were used separately in mixture. After 40 cycles of PCR by using " $94^{\circ} \mathrm{C} 40$ seconds, $58^{\circ} \mathrm{C} 40$ seconds, $72^{\circ} \mathrm{C} 45$ seconds" program, final product was loaded to 2\% agarose gel. After electrophoresis, gel was examined by using UV transilluminator for absence or presence, location and, size of bands.

The medical ethics committee of Erciyes University approved this study and informed consent was obtained from all patients.

\section{RESULTS}

In our ten cases, mean age at diagnosis was 30.4 , mean body height was $166.9 \mathrm{~cm}$ (lower than general population), mean body weight was $72.6 \mathrm{~kg}$, mean BMI was 26.02. Semen analysis showed azoospermia and average semen volume was $1.68 \mathrm{~mL}$. All cases had small testicular volumes. Mean testicular volume was $3.1 \mathrm{~mL}$ for right testes and $2.5 \mathrm{~mL}$ for left testes. Detailed general characteristics of the cases are presented in Table- 1 .

Two of the patients (patients 3,10) had prior orchiopexy operation in their medical history and one of them (patient 3) had parental consanguinity. All patients had no family history for genetic disorders.

Four patients (patients 1, 5, 9, 10) had decreased axillary and pubic hair and one patient (patient 5) had gynecomastia Tanner stage III.

Hormonal data indicated that the patients had a higher FSH, LH levels, lower TT level and normal E2, PRL levels (Table-2).

Three patients had dual-energy x-ray absorptiometry (DEXA) assessment. First one 
Table 1 - Clinical data and semen volume analysis.

\begin{tabular}{lcccccc}
\hline Cases & $\begin{array}{c}\text { Age } \\
(\text { years })\end{array}$ & $\begin{array}{c}\text { Height } \\
(\mathrm{cm})\end{array}$ & $\begin{array}{c}\text { Weight } \\
(\mathrm{kg})\end{array}$ & $\begin{array}{c}\text { BMl } \\
(\mathrm{kg} / \mathrm{m} 2)\end{array}$ & TV $(\mathrm{R} / \mathrm{L})(\mathrm{mL})$ & $\begin{array}{c}\text { EV } \\
(\mathrm{mL})\end{array}$ \\
\hline 1 & 26 & 170 & 63 & 21.8 & $6 / 5$ & 2.4 \\
2 & 31 & 167 & 72 & 25.8 & $2 / 2$ & 2.5 \\
3 & 28 & 169 & 71 & 24.9 & $5 / 1$ & 1.6 \\
4 & 30 & 170 & 72 & 24.9 & $2 / 2$ & 1.1 \\
5 & 39 & 161 & 74 & 28.5 & $3 / 3$ & 2 \\
6 & 40 & 168 & 81 & 28.7 & $5 / 4$ & 2.5 \\
7 & 30 & 162 & 66 & 25.1 & $4 / 3$ & 3.2 \\
8 & 28 & 165 & 68 & 25 & $1 / 1$ & 0.2 \\
9 & 24 & 163 & 66 & 24.8 & $1 / 1$ & 0.1 \\
10 & 28 & 174 & 93 & 30.7 & $2 / 3$ & 1.2 \\
\hline Mean & 30.4 & 166.9 & 72.6 & 26.02 & $3.1 / 2.5$ & 1.68 \\
\hline
\end{tabular}

$\mathbf{B M I}=$ Body Mass Index; TV = Testicular Volume; EV = Ejaculate Volume; $\mathbf{R}$ = Right; $\mathbf{L}$ = Left

Table 2 - Hormonal status of the patients.

\begin{tabular}{lccccc}
\hline Cases & $\begin{array}{c}\mathrm{FSH} \\
(\mathrm{mlU} / \mathrm{mL})\end{array}$ & $\begin{array}{c}\mathrm{LH} \\
(\mathrm{mlU} / \mathrm{mL})\end{array}$ & $\begin{array}{c}\mathrm{E} 2 \\
(\mathrm{pg} / \mathrm{mL})\end{array}$ & $\begin{array}{c}\mathrm{TT} \\
(\mathrm{ng} / \mathrm{dL})\end{array}$ & $\begin{array}{c}\mathrm{PRL} \\
(\mathrm{ng} / \mathrm{mL})\end{array}$ \\
\hline 1 & 58.1 & 42.2 & 52.0 & 183.0 & 5.6 \\
2 & 36.0 & 16.8 & 57.9 & 376.0 & 3.5 \\
3 & 35.4 & 9.5 & 48.6 & 94.4 & 8.1 \\
4 & 17.9 & 10.3 & 24.6 & 272.7 & 7.9 \\
5 & 37.5 & 16.3 & 24.5 & 96.6 & 6.9 \\
6 & 36.8 & 9.8 & 53.8 & 290.0 & 5.6 \\
7 & 57.3 & 16.9 & 49.2 & 153.6 & 6.4 \\
8 & 50.5 & 11.3 & 39.1 & 103.0 & 9.0 \\
9 & 43.1 & 17.9 & 21.2 & 242.0 & 8.6 \\
10 & 31.3 & 23.5 & 27.6 & 203.0 & 9.0 \\
\hline Mean and $95 \% \mathrm{Cl}$ & $40.4(31.5-49.2)$ & $17.4(10.4-24.4)$ & $39.8(29.7-49.9)$ & $201.4(134.0-268.7)$ & $7.1(5.8-8.3)$
\end{tabular}

FSH = Follicle-stimulating Hormone (1.5 -12.4 mIU/mL); LH = Luteinizing Hormone (1.7-8.6 mlU/mL); E2 = Estradiole (25.8-60.7 pg/mL); PRL = Prolactin (4.0-15.2 ng/ $\mathrm{mL}) ; \mathbf{T T}=$ Total Testosterone $(280-800 \mathrm{ng} / \mathrm{dL}) ; \mathbf{9 5} \% \mathbf{C I}=$ Confidence interval of mean References interval of hormones (FSH, LH, E2, PRL, TT) are given in parentheses

(Patient 5) was assessed osteopenic for lumbar vertebraes and femoral neck; second one $(\mathrm{Pa}-$ tient 8) was assessed osteopenic for lumbar vertebraes and third one (Patient 7) was assessed osteoporotic for lumbar vertebraes and osteopenic for femoral neck.

Initial karyotyping analysis of all patients were considered as 46 , XX with some hesitation because of derivative $\mathrm{X}$ chromosomes observed in metaphase fields. After fluorescence in situ hybridization (FISH) analysis, it was revealed that all patients were SRY posi- tive. Next step which was the determination of the presence or the deletion of AZFa, AZFb, and $A Z F c$ regions revealed that all these regions were deleted in eight patients, in one patient (patient 9) none of the regions were deleted and in one patient (patient 2) AZFb and AZFc regions were deleted and AZFa was present.

Final karyotype for patients was as 46,XX, final FISH report was written as 46,XX ish der (X) $\mathrm{t}(\mathrm{X} ; \mathrm{Y})(\mathrm{p} 22.3 ; \mathrm{p} 11.3)(\mathrm{SRY}+)$ and AZF region deletion summarized in Table-3. Presumable Ideogram of the chromosomes is given in Figure-1. 
Table 3 - AZF region analysis of the patients.

\begin{tabular}{lccc}
\hline Patient & $\begin{array}{c}\text { AZFa } \\
\text { region }\end{array}$ & $\begin{array}{c}\text { AZFb } \\
\text { region }\end{array}$ & $\begin{array}{c}\text { AZFc } \\
\text { region }\end{array}$ \\
\hline 1 & - & - & - \\
2 & + & - & - \\
3 & - & - & - \\
4 & - & - & - \\
5 & - & - & - \\
6 & - & - & - \\
7 & - & - & - \\
8 & - & - & + \\
9 & + & + & - \\
10 & - & - & - \\
\hline
\end{tabular}

- deletion of gene region; + presence of gene region

Figure 1 - Presumable Ideogram of chromosomes.

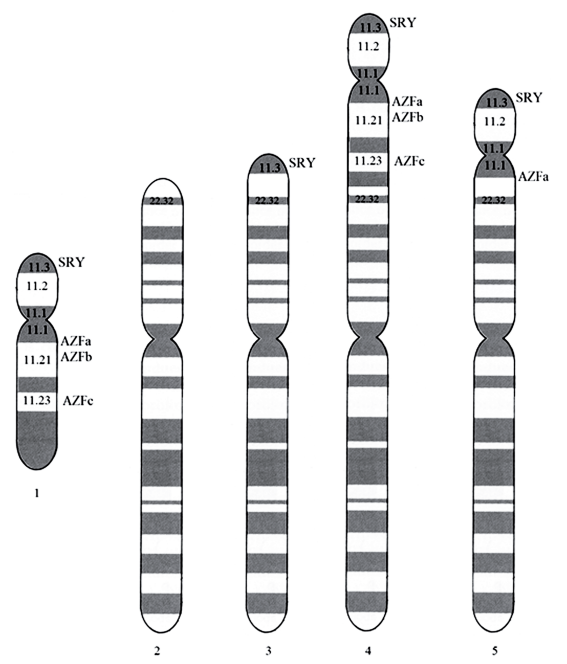

1 - Normal $Y$ Chromosome; 2 - Normal $X$ Chromosome; 3 - Derivative $X$ Chromosome of cases number 1, 3-8, and 10; $\mathbf{4}$ - Derivative $X$ Chromosome of case 2; $\mathbf{5}$ - Derivative X Chromosome of case 9.

\section{DISCUSSION}

$46, \mathrm{XX}$ testicular DSD is a rare sex reversal syndrome characterized by a female karyotype in discordance with a male phenotype (4). Although 46,XX male DSD is frequently sporadic (8), familial cases have also been reported
(9). All our patients were considered sporadic based on their family history.

46,XX testicular DSD patients can be classified into two groups according to presence or absence of SRY gene (10). Appearance of the external genitalia and masculinization are usually normal in 46,XX SRY-positive testicular DSD cases (4). Before puberty there is no clinical sign except for undescended testis and therefore 46,XX SRY-positive males are usually diagnosed in late adolescence or adulthood through chromosome analyses performed for infertility and/or small testis (11). Two patients had prior orchiopexy operation in their medical history, although, chromosomal analysis is not required for all patients with undescended testes. Possibility of chromosomal abnormality should be kept in mind for azoospermic patients who had prior orchiopexy history. Furthermore, it is a well-known fact that infertile men have 8 to 10 times more chromosomal anomalies than fertile men do, and many times, do not present with other phenotypic characteristics (12). Based on prevalence data, recommendation is made that routine karyotyping be requested of infertile men with deficient spermatogenesis and sperm concentrations lower than 10 million/mL before they are submitted to any assisted reproduction technique (13). 
Vorona et al. stated that 46,XX men tend to be shorter than men with Klinefelter syndrome (7). In a previous study, Y chromosome growth-control gene had a possible impact on growth (14). Mean body height was relatively lower than normal population in our cases. Absence of specific growth genes in the $Y$ chromosome may have some effects for this situation.

Classical 46,XX testicular DSD have normal testosterone level and free testosterone level during adolescence, but may decrease in adulthood, leading to hypergonadotropic hypogonadism (15). Testicular volumes are usually lower than $5 \mathrm{~mL}$ in these cases. While testis morphology is normal in infancy, hyalinization of the seminiferous tubules in early childhood causes loss of spermatogonia $(16,17)$. Gunes et al. showed hyalinization of the seminiferous tubules by testicular biopsies of a patient with 46,XX testicular DSD (18). Low testicular volume and hypergonadotropic hypogonadism are constant findings in our patients. But testicular biopsies were not performed because these patients had no chance of bearing a child by assisted reproductive techniques.

Imaging of the pelvis is required to look for remnants of mullerian ducts that may cause morbidity in the form of repeated infections or hematuria and require surgical removal $(19,20)$. Differential diagnosis with other genetic conditions such as Persistent Mullerian Duct Syndrome in which virilization is achieved despite having low testosterone levels may be a challenging issue in some clinical presentations.

Recent epidemiologic studies have suggested that hypogonadal concentrations of TT are associated with an increased risk of fragility fracture $(21,22)$. Replacement therapies may protect these patients from bone fracture risk. Prior to initiating therapy, a baseline bone density scan should be performed to look for osteopenia or frank osteoporosis (23). Patients with a T score of $<-1.0$ would benefit from treatment with Vitamin D and calcium, bisphosphonates, or calcitonin, and require annual repeats of DEXA scan until results are normal (16). Our three patients had DEXA assay and all of them were assessed as osteopenic or osteoporotic. Bone mineral density measurements were absent in the records of our initial patients. We began to perform these measurements and apply replacement therapies as our clinical experience increased. Important part of individuals with SRY-positive 46,XX testicular DSD are diagnosed at adulthood in infertility clinics. But testosterone replacement should be given to patients which have clinical and/or laboratory signs of androgen deficiency in puberty.

During genetic counselling, it was advised to patients that this report must not affect their life and they must continue to live as before. While explaining inheritance it was stated that SRY-positive 46 , XX testicular DSD is generally not inherited because of infertility of patients and de novo occurrence of $\mathrm{Y}$ and $\mathrm{X}$ chromosome translocation. But as there is always possibility of paternal balanced translocation or gonadal mosaicism, chromosome analyses were advised to father and brothers.

In conclusion, chromosomal abnormalities such as SRY-positive 46,XX testicular DSD can be diagnosed in infertility clinics during infertility work-up. Although these patients had no chance of bearing a child, they should be protected from negative effects of testosterone deficiency by replacement therapies.

\section{CONFLICT OF INTEREST}

None declared.

\section{REFERENCES}

1. Zenteno-Ruiz JC, Kofman-Alfaro S, Méndez JP. 46,XX sex reversal. Arch Med Res. 2001;32:559-66.

2. Delachapelle A, Hortling H, Miemi M, Wennstroem J. XX sex chromosomes in a human male. First case. Acta Med Scand. 1964;175:(Suppl 412):25-8.

3. Rego A, Margarit E, Estivill X, Regal M, García-Mayor RV. Development in a $46 \mathrm{XX}$ boy with positive SRY gene. J Pediatr Endocrinol Metab. 1996;9:623-6.

4. Ergun-Longmire B, Vinci G, Alonso L, Matthew S, Tansil S, Lin-Su K, et al. Clinical, hormonal and cytogenetic evaluation of $46, \mathrm{XX}$ males and review of the literature. J Pediatr Endocrinol Metab. 2005;18:739-48.

5. Anık A, Çatlı G, Abacı A, Böber E. 46,XX male disorder of sexual development:a case report. J Clin Res Pediatr Endocrinol. 2013;5:258-60.

6. Jain M, V V, Chaudhary I, Halder A. The Sertoli Cell Only Syndrome and Glaucoma in a Sex-Determining Region Y (SRY) Positive XX Infertile Male. J Clin Diagn Res. 2013;7:1457-9. 
7. Vorona E, Zitzmann M, Gromoll J, Schüring AN, Nieschlag E. Clinical, endocrinological, and epigenetic features of the 46,XX male syndrome, compared with 47,XXY Klinefelter patients. J Clin Endocrinol Metab. 2007;92:3458-65.

8. Fechner PY, Marcantonio SM, Jaswaney V, Stetten G, Goodfellow PN, Migeon CJ, et al. The role of the sexdetermining region $\mathrm{Y}$ gene in the etiology of $46, \mathrm{XX}$ maleness. J Clin Endocrinol Metab. 1993;76:690-5.

9. Zenteno JC, López M, Vera C, Méndez JP, Kofman-Alfaro S. Two SRY-negative XX male brothers without genital ambiguity. Hum Genet. 1997;100:606-10.

10. Ferguson-Smith MA, Cooke A, Affara NA, Boyd E, Tolmie $\mathrm{JL}$. Genotype-phenotype correlations in XX males and their bearing on current theories of sex determination. Hum Genet. 1990;84:198-202.

11. Wang T, Liu JH, Yang J, Chen J, Ye ZQ. 46, XX male sex reversal syndrome: a case report and review of the genetic basis. Andrologia. 2009;41:59-62.

12. Bianco B, Christofolini DM, Ghersel FR, Gava MM, Barbosa CP. XX testicular disorder of sex differentiation: case report. Einstein (Sao Paulo). 2011;9:394-6.

13. McLachlan RI, O'Bryan MK. Clinical Review\#: State of the art for genetic testing of infertile men. J Clin Endocrinol Metab. 2010;95:1013-24.

14. Kirsch S, Weiss B, Schön K, Rappold GA. The definition of the $Y$ chromosome growth-control gene (GCY) critical region: relevance of terminal and interstitial deletions. $J$ Pediatr Endocrinol Metab. 2002;15 Suppl 5:1295-300.

15. Velasco G, Savarese V, Sandorfi N, Jimenez SA, Jabbour S. 46, XX SRY-positive male syndrome presenting with primary hypogonadism in the setting of scleroderma.Endocr Pract. 2011:17:95-8.

16. Boucekkine C, Toublanc JE, Abbas N, Chaabouni S, Ouahid $\mathrm{S}$, Semrouni $\mathrm{M}$, et al. Clinical and anatomical spectrum in $X X$ sex reversed patients. Relationship to the presence of $\mathrm{Y}$ specific DNA-sequences. Clin Endocrinol (Oxf). 1994:40:733-42.
17. Abbas NE, Toublanc JE, Boucekkine C, Toublanc M, Affara $\mathrm{NA}$, Job JC, et al. A possible common origin of "Y-negative" human $X X$ males and $X X$ true hermaphrodites. Hum Genet. 1990;84:356-60.

18. Gunes S, Asci R, Okten G, Atac F, Onat OE, Ogur G, et al. Two males with SRY-positive 46,XX testicular disorder of sex development. Syst Biol Reprod Med. 2013;59:42-7.

19. Morgan RJ, Williams DI, Pryor JP. Müllerian duct remnants in the male. Br J Urol. 1979;51:488-92.

20. Da Aw L, Zain MM, Esteves SC, Humaidan P. Persistent Mullerian Duct Syndrome: a rare entity with a rare presentation in need of multidisciplinary management. Int Braz J Urol. 2016;42:1237-1243.

21. Cawthon PM, Ensrud KE, Laughlin GA, Cauley JA, Dam TT, Barrett-Connor E, et al. Sex hormones and frailty in older men: the osteoporotic fractures in men (MrOS) study. J Clin Endocrinol Metab. 2009;94:3806-15.

22. Meier C, Nguyen TV, Handelsman DJ, Schindler C, Kushnir MM, Rockwood AL, et al. Endogenous sex hormones and incident fracture risk in older men: the Dubbo 0steoporosis Epidemiology Study. Arch Intern Med. 2008;168:47-54.

23. Majzoub A, Arafa M, Starks C, Elbardisi H, Al Said S, Sabanegh E. 46 XX karyotype during male fertility evaluation; case series and literature review. Asian J Androl. 2017;19:168-172.

Correspondence address:

Akinsal, Emre Can, MD Department of Urology

Erciyes University Medical Faculty, Kayseri, Turkey 38280, Melikgazi, Kayseri, Turkey Fax: + 90352 437-5285 E-mail: emreakinsal@hotmail.com 